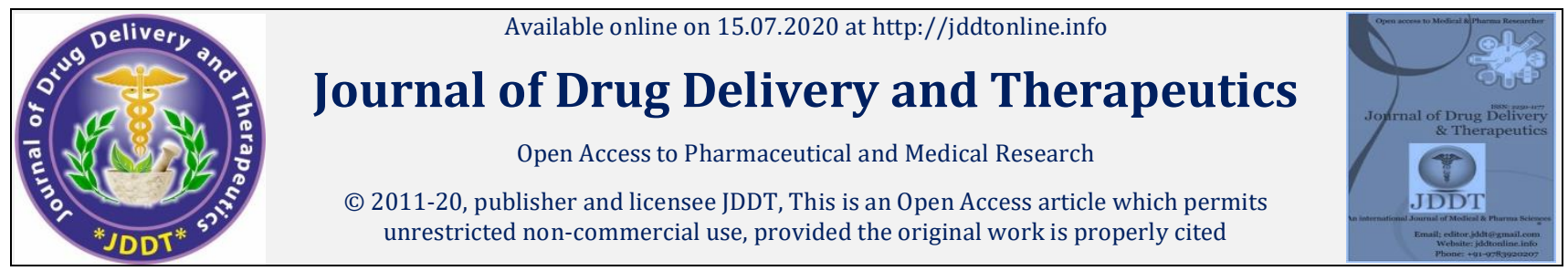

Open $\odot$ Access

Research Article

\title{
Free Radical Scavenging Activity, Reducing Power and Anti-Hemolytic Capacity of Algerian Drimia maritima Baker Flower Extracts
}

\author{
Abir Rezzagui 1,2 *, Abderrahmane Senator ${ }^{1,3}$, Soumia Benbrinis ${ }^{1}$, and Hamama Bouriche 1 \\ ${ }^{1}$ Laboratory of Applied Biochemistry, Faculty of Natural and Life Sciences, University Ferhat Abbas, Sétif 1, Sétif 19000, Algeria \\ 2 Department of Molecular and Cellular Biology, Faculty of Natural and Life Sciences, University of Jijel, Jijel 18000, Algeria \\ ${ }^{3}$ Faculty of Natural and Life Sciences, University of Batna 2, Batna 5000, Algeria
}

\begin{abstract}
This study was undertaken to evaluate the antioxidant and anti-hemolytic properties of Algerian Drimia maritima Baker flower extracts. Determination of phenolic content was carried out to estimate the chemical composition of D. maritima extracts. Antioxidant properties were investigated in all extracts using free radical scavenging activity (against DPPH, ABTS, hydroxyl radical, and superoxide anion), reducing power, inhibition of lipid peroxidation, and anti-hemolytic capacity. Phenolic determination revealed that $D$. maritima flowers contain phenolic compounds, flavonoids, and tannins. Ethyl acetate extract showed the highest reducing power and scavenging activity using DPPH and ABTS assays. However, aqueous extract was the most effective against hydroxyl radical, superoxide anion, and lipid peroxidation. The half-time of hemolysis indicates that chloroform extract exhibited the best anti-hemolytic capacity in the AAPH induced hemolysis model. The results of this study suggest that D. maritima could be used as a possible source of antioxidant phenolic compounds and that further determination of these compounds may provide more information on their medicinal value.
\end{abstract}

Keywords: Drimia maritima, phenolic compounds, scavenging activity, reducing power, anti-hemolytic.

Article Info: Received 22 April 2020; Review Completed 17 June 2020; Accepted 25 June 2020; Available online 15 July 2020

\section{Cite this article as:}

Rezzagui A, Senator A, Benbrinis S, Bouriche H, Free Radical Scavenging Activity, Reducing Power and Anti-Hemolytic Capacity of Algerian Drimia maritima Baker Flower Extracts, Journal of Drug Delivery and Therapeutics. 2020; 10(4):7078 http://dx.doi.org/10.22270/jddt.v10i4.4142

*Address for Correspondence:

Abir Rezzagui, Laboratory of Applied Biochemistry, Faculty of Natural and Life Sciences, University Ferhat Abbas, Sétif 1, Sétif 19000, Algeria

\section{INTRODUCTION}

For many years, medicinal plants have been considered as a very important source of chemical substances with therapeutic effects. Thus, study of plants spices with traditional use as pain killers should be sees as a logical strategy in search for new drugs. Drimia maritima $(D$. maritima) is a wild-growing bulbous plant belonging to the family Asparagaceae. It is mainly distributed in slopes of hills and sandy soils of the Mediterranean Sea and North Africa1. In folk medicine, the bulb of this plant is used for the treatment of heart failure, chronic bronchitis, asthma, pneumonia, wounds, hemorrhoids, bites of vipers, jaundice and as a diuretic 2,3 . It is also used to treat dermatological problems, ear pain ${ }^{4}$, digestive disorders 5 , whooping cough 6 and hepatitis?.

Several beneficial effects of D. maritima are attributed to the presence of many bioactive compounds. The most known are anthocyanins, flavonoids ${ }^{8}$, fatty acids, polysaccharides ${ }^{9}$, tannins, reducing compounds, anthraquinones, triterpenes, steroids ${ }^{10}$ and cardiac glycosides (bufadienolids type) that are the major compounds with $1-3 \%$ of the bulb dry weight 11 .

However, to our knowledge, no report is available on phenolic content and antioxidant activity of D. maritima flowers. So, the aim of the present study is to evaluate the radical scavenging activity and anti-hemolytic property of $D$. maritima flower extracts and their phenolic fractions, to understand the usefulness of this plant in traditional medicine.

\section{MATERIAL AND METHODS}

\section{Plant material}

Fresh D. maritima flowers were collected from Mila (east of Algeria), during the flowering season (October 2017). The plant material was air-dried in dark at room temperature and then ground to a powder using a manual grinder. 


\section{Preparation of extracts}

The crud ethanolic extract (CRE) was prepared by macerating $100 \mathrm{~g}$ of flower powder in $1000 \mathrm{~mL}$ of $80 \%$ ethanol with occasional shaking and the resulting macerate was filtered. These steps were repeated another time with the $50 \%$ ethanol. The resulting filtrate was evaporated under reduced pressure at $45^{\circ} \mathrm{C}$. The filtrate was then washed with hexane several times until a clear upper layer of hexane was obtained. The lower layer was then extracted successively with chloroform and ethyl acetate to obtain at the end of the extraction process 2 fractions; chloroform fraction (CHE) and ethyl acetate fraction (EAE). Then solvents were removed using a rotary evaporator.

Aqueous extract (AQE) was prepared using an infusion of $100 \mathrm{~g}$ of flower powder in $1000 \mathrm{~mL}$ of boiling distilled water for $15 \mathrm{~min}$. After filtration and evaporation, the yield of each extract and fraction was determined before kept them in $4^{\circ} \mathrm{C}$ until use.

\section{Determination of phenolic content}

\section{Total phenolic content}

The Folin-Ciocalteu reagent was used to determine total phenolic content in extracts ${ }^{12}$. A $100 \mu \mathrm{L}$ of samples at different concentrations $(1,2.5,5 \mathrm{mg} / \mathrm{ml})$ was mixed with $500 \mu \mathrm{L}$ of Folin-Ciocalteau reagent $(10 \%$ in distilled water). After $4 \mathrm{~min}, 400 \mu \mathrm{L}$ of $7.5 \%$ of $\mathrm{Na}_{2} \mathrm{CO}_{3}$ solution were added. After incubation for $90 \mathrm{~min}$ at room temperature, the absorbance was measured at $760 \mathrm{~nm}$ and the results were expressed in mg of gallic acid equivalent per gram of extract (GAE/g).

\section{Total flavonoid content}

A volume of each sample $(1,2.5$, and $5 \mathrm{mg} / \mathrm{ml})$ was mixed with an equal volume of aluminum chloride $(2 \%$ in methanol) solution ${ }^{13}$. After incubation for $10 \mathrm{~min}$, the absorbance was measured at $430 \mathrm{~nm}$. All values were expressed as mg of quercetin equivalent per gram of extract (QE/g).

\section{Total tannin content}

The tannin content was determined according to the method described by Batesmith ${ }^{14}$. Briefly, $1 \mathrm{~mL}$ of each extract at different concentrations $(1,2.5,5 \mathrm{mg} / \mathrm{ml})$ was mixed with $1 \mathrm{~mL}$ of hemolyzed bovine blood (absorbance $=1.6$ ). After $20 \mathrm{~min}$, the mixture was centrifuged at $4000 \mathrm{rpm}$ for $10 \mathrm{~min}$ and the absorbance of the supernatant was measured at $756 \mathrm{~nm}$. The results were expressed in mg equivalent of tannic acid per gram of extract (mg TAE/g).

\section{Antioxidant activity}

\section{DPPH assay}

A $500 \mu \mathrm{L}$ of different concentrations $(0-350 \mu \mathrm{g} / \mathrm{ml})$ of the extracts were added to $500 \mu \mathrm{L}$ of DPPH solution $(0.078 \mathrm{mg} / \mathrm{mL})$. After incubation for $30 \mathrm{~min}$ at room temperature, the absorbance was measured at $517 \mathrm{~nm}$. BHT was used as a standard. The ability of extracts to scavenge DPPH radicals was calculated by the following equation ${ }^{15}$ :

$\mathrm{DPPH}$ radical scavenging activity $(\%)=\left(\mathrm{A}_{\mathrm{C}}-\mathrm{A}_{\mathrm{S}} / \mathrm{A}_{\mathrm{C}}\right) \times 100$

Ac: absorbance without sample,

As : absorbance in the presence of the sample.

\section{ABTS assay}

ABTS cationic radical $\left(\mathrm{ABTS}^{\bullet}\right)$ was produced by reacting ABTS stock solution $(7 \mathrm{mM})$ with $2.45 \mathrm{mM}$ potassium persulfate and allowing the mixture to stand at room temperature in the dark for 12-16 hours before use ${ }^{16}$. Then, the solution was diluted with methanol and equilibrated to give an absorbance of $0.700 \pm 0.02$ at $734 \mathrm{~nm}$. The scavenging activity was estimated by mixing $50 \mu \mathrm{L}$ of extracts at different concentrations $(0-50 \mu \mathrm{g} / \mathrm{ml})$ or BHT with $1 \mathrm{~mL}$ of $\mathrm{ABTS}^{\bullet+}$ solution and absorbance was measured after $30 \mathrm{~min}$ of incubation at room temperature. The antioxidant activity was calculated as the following equation:

$$
\mathrm{ABTS}^{\bullet}+\text { scavenging activity }(\%)=\left(\mathrm{A}_{\mathrm{C}}-\mathrm{A}_{\mathrm{S}} / \mathrm{A}_{\mathrm{C}}\right) \times 100
$$

Ac: absorbance without sample.

As: absorbance in the presence of the sample.

\section{Superoxide anion scavenging activity}

The superoxide anion scavenging activity was measured as described by Robak and Gryglewski ${ }^{17}$. These radicals are generated in $3 \mathrm{~mL}$ of Tris-HCl buffer $(16 \mathrm{mM}, \mathrm{pH} 8.0)$, containing $500 \mu \mathrm{L}$ of nitroblue tetrazolium (NBT) $(0.3 \mathrm{mM})$, $500 \mu \mathrm{L}$ NADH $(0.936 \mathrm{mM})$ solution, $1 \mathrm{~mL}$ of extract at different concentrations $(0-1000 \mu \mathrm{g} / \mathrm{ml})$ and $500 \mu \mathrm{L}$ Tris-HCl buffer $(16 \mathrm{mM}, \mathrm{pH} 8.0)$. The reaction was initiated by adding a $500 \mu \mathrm{L}$ of phenazine methosulfate (PMS) solution $(0.12 \mathrm{mM})$ to the mixture. After incubation at $25^{\circ} \mathrm{C}$ for $5 \mathrm{~min}$, the absorbance was measured at $560 \mathrm{~nm}$. The antioxidant activity was calculated as the following equation:

Superoxide anion radical scavenging activity $(\%)=\left(\mathrm{Ac}_{\mathrm{c}}-\mathrm{As}_{\mathrm{s}} / \mathrm{Ac}_{\mathrm{c}}\right) \mathrm{x} 100$.

Ac: absorbance without sample.

As: absorbance in the presence of the sample.

\section{Hydroxyl radical scavenging activity}

The scavenging ability of hydroxyl radicals was measured according to the method of Smirnoff and Cumbes ${ }^{18}$. The reaction mixture consists of $1 \mathrm{~mL}$ of ferrous sulfate $(1.5 \mathrm{mM})$, $700 \mu \mathrm{L}$ of hydrogen peroxide $(6 \mathrm{mM}), 300 \mu \mathrm{L}$ of sodium salicylate $(20 \mathrm{mM})$, and $1 \mathrm{~mL}$ of extracts at different concentrations $(0-500 \mu \mathrm{g} / \mathrm{ml})$ or ascorbic acid. After incubation at $37^{\circ} \mathrm{C}$ for 1 hour and cooling, the absorbance was measured at $562 \mathrm{~nm}$. The antioxidant activity was calculated as the following equation:

Hydroxyl radical scavenging activity $(\%)=\left[1-\left(A_{s}-A_{B} / A_{c}\right)\right] \times 100$

Ac: absorbance without sample,

$\mathbf{A}_{\mathbf{B}}$ : absorbance of the blank (without sodium salicylate),

As: absorbance in the presence of the sample.

\section{Reducing power}

The ferric reducing capacity of the extracts was determined according to the method described by Prasad et al. ${ }^{19}$. So, $2.5 \mathrm{~mL}$ of $0.2 \mathrm{M}$ phosphate buffer $(\mathrm{pH} 6.6)$ and $2.5 \mathrm{~mL}$ of $\mathrm{K}_{3} \mathrm{Fe}(\mathrm{CN})_{6}(1 \%)$ were added to $1 \mathrm{~mL}$ of sample at different concentrations $(0-95 \mu \mathrm{g} / \mathrm{ml})$ dissolved in distilled water. The resulting mixture was incubated at $50^{\circ} \mathrm{C}$ for $20 \mathrm{~min}$, followed by the addition of $2.5 \mathrm{~mL}$ of trichloroacetic acid (10\%). The mixture was centrifuged at $3000 \mathrm{rpm}$ for $10 \mathrm{~min}$ to collect the upper layer of the solution $(2.5 \mathrm{~mL})$, which was mixed with $2.5 \mathrm{~mL}$ of distilled water and $500 \mu \mathrm{L}$ of $\mathrm{FeCl}_{3}(0.1 \%)$. The absorbance was then measured at $700 \mathrm{~nm}$. The Reducing power was represented as $\mathrm{EC}_{50}$ (effective concentration of the sample necessary to obtain 0.5 absorbance at $700 \mathrm{~nm}$ ).

\section{$\beta$-carotene / linoleic acid essay}

The ability of extracts to prevent bleaching of $\beta$-carotene was assessed as described by Kartal et al.20. A stock emulsion of $\beta$-carotene/linoleic acid was freshly prepared by dissolving $0.5 \mathrm{mg}$ of $\beta$-carotene in $1 \mathrm{~mL}$ of chloroform, $25 \mu \mathrm{l}$ of linoleic acid, and $200 \mathrm{mg}$ of Tween 40 . The chloroform was completely evaporated under vacuum in a rotatory 
evaporator at $40^{\circ} \mathrm{C}$, then $100 \mathrm{~mL}$ of distilled water was added and the resulting mixture was vigorously stirred. Aliquots $(2.5 \mathrm{~mL})$ of the $\beta$-carotene/linoleic acid emulsion were transferred to test tubes containing $500 \mu \mathrm{L}$ of each sample $(400 \mu \mathrm{g} / \mathrm{ml})$ and the absorbance was measured at $470 \mathrm{~nm}$. The antioxidant activity was calculated as the following equation:

$$
\text { Antioxidant activity }(\%)=\left(\mathrm{A}_{\mathrm{t}}(\text { extract }) / \mathrm{A}_{\mathrm{t}}(\mathrm{BHT})\right) \mathrm{x} 100
$$

At (extract): absorbance in the presence of extract at a specific time.

$\mathbf{A}_{\mathbf{t}}$ (BHT): absorbance in the presence of the BHT at the same time.

\section{Anti-hemolytic activity}

The inhibition of AAPH-induced hemolysis in red blood cells (RBC) was determined according to Takebayashi et al.21. Briefly, AAPH (2.2-azobis (2-amidinopropane) dihydrochloride) dissolved in phosphate buffer solution (PBS, pH 7.4) was used to induce the oxidation chain in erythrocytes. Blood from a rat was collected in a tube containing $0.1 \%$ EDTA, centrifuged at $6000 \mathrm{rpm}$ for $10 \mathrm{~min}$ and washed three times with PBS. Then, $100 \mu \mathrm{L}$ of the resulting red blood cells were immediately diluted to $2 \%$ by adding $4.9 \mathrm{~mL}$ of PBS. To assess the anti-hemolytic activity of extracts, $120 \mu \mathrm{L}$ of the blood solution was pre-incubated at $37^{\circ} \mathrm{C}$, for $15 \mathrm{~min}$, with $60 \mu \mathrm{L}$ of extracts or Trolox $(12.5,25$ and $50 \mu \mathrm{g} / \mathrm{ml})$. After that, $120 \mu \mathrm{L}$ of AAPH solution $(300 \mathrm{mM})$ was added and the reaction mixtures were then incubated at $37^{\circ} \mathrm{C}$ for $4-5$ hours. The degree of hemolysis was determined every $30 \mathrm{~min}$ at $620 \mathrm{~nm}$ using a 96 -well micro-plate reader (ELX 800 de Bio-TEK instruments). The RBC hemolysis was calculated as the following equation:

$$
\mathrm{RBC} \text { hemolysis }(\%)=\left(\mathrm{A}_{0}-\mathrm{Ax}_{\mathrm{x}} / \mathrm{A}_{0}-\mathrm{A}_{\text {Final }}\right) \times 100
$$

A0: absorbance at the start of the experience.

Ax: absorbance at a specific time.

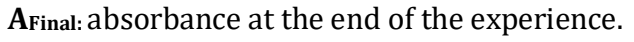

$\mathrm{RBC}$ resistance to the AAPH-induced hemolysis is estimated using the half time of hemolysis $\left(\mathrm{HT}_{50}\right)$ which corresponds to the necessary time to induce hemolysis of $50 \%$ of initial erythrocytes.

\section{Statistical analysis}

Results were expressed as means of triplicate \pm SD. Data were statistically analyzed with Graph Pad Prism ${ }^{\circledR}$ version 8.0.1, using one-way analysis of variance (ANOVA) and samples differences were extrapolated by Tukey's multiple comparison test. Differences are considered significant when $\mathrm{P}<0.05$.

\section{RESULTS}

Extraction yield, total phenolic, flavonoid and tannin content

Table 1 presents the results obtained for yield, total phenolic, flavonoid, and tannin content of D. maritima extracts. The results revealed that higher levels of total phenolics, flavonoids, and tannins were observed in EAE compared to the other extracts (Table 1).

Table 1: Yield, total phenolic, flavonoid and tannin content of D. maritima extracts

\begin{tabular}{|l|c|c|c|c|}
\hline \multicolumn{1}{|c|}{ Extract } & $\begin{array}{c}\text { Yield } \\
\text { (\%) }\end{array}$ & $\begin{array}{c}\text { Total phenolic } \\
\text { (mg of GAE/g of extract) }\end{array}$ & $\begin{array}{c}\text { Total flavonoid } \\
\text { (mg of QE/g of extract) }\end{array}$ & $\begin{array}{c}\text { Total tannin } \\
\text { (mg of TAE/g of extract) }\end{array}$ \\
\hline AQE & 20.4 & $68.7 \pm 3.1$ & $3.45 \pm 0.1$ & $391.1 \pm 17.3$ \\
\hline CRE & 24.9 & $66.9 \pm 1.4$ & $5.31 \pm 0.03$ & $314.4 \pm 3.3$ \\
\hline EAE & 3 & $100.4 \pm 1.3$ & $29.19 \pm 0.2$ & $471.8 \pm 0.2$ \\
\hline CHE & 1.7 & $73.6 \pm 3.2$ & $9.49 \pm 0.2$ & $422.7 \pm 3.5$ \\
\hline
\end{tabular}

\section{Antioxidant activity}

\section{DPPH radical scavenging activity}

Data presented in Figure 1 showed that various extracts of D. maritima, at different concentrations, exerted scavenging activity against DPPH radicals in a concentration-dependent manner. Among all extracts, EAE and AQE were the most effective extracts with the lowest IC50 values. These values are close to those obtained with BHT (Table 2).

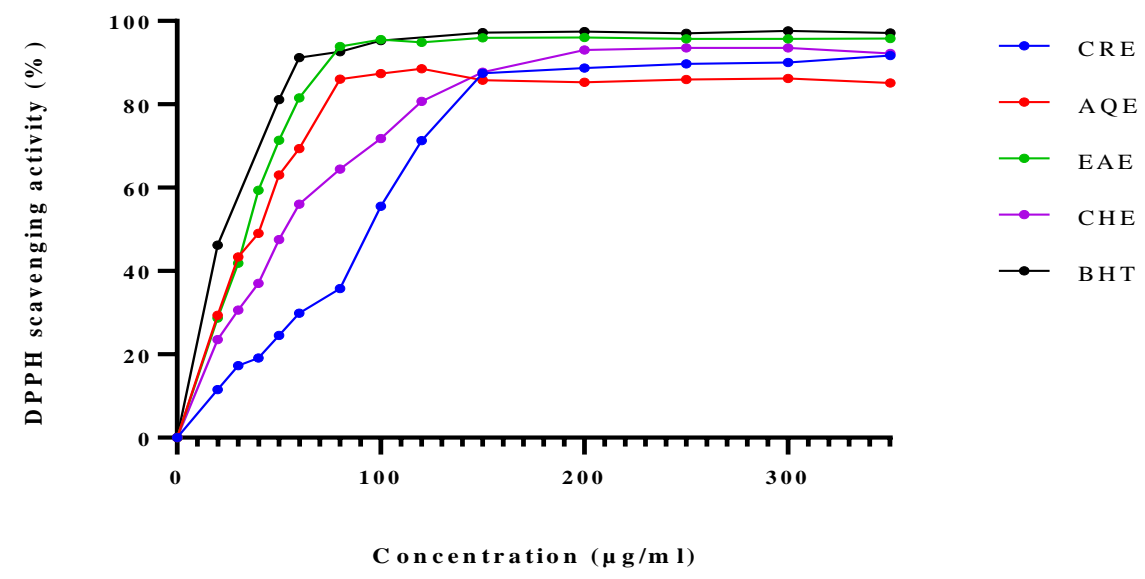

Figure 1: DPPH radical scavenging activity of D. maritima extracts and BHT. Values are means of triplicate determinations $(n=3) \pm S D$. 
Table 2: $\mathrm{IC}_{50}$ and $\mathrm{EC}_{50}$ of D. maritima extracts in ABTS, reducing power, DPPH, anion superoxide, and hydroxyl radical assays.

\begin{tabular}{|c|c|c|c|c|c|}
\hline Samples & $\begin{array}{c}\text { DPPH } \\
\left(\mathrm{IC}_{50, \mu \mathrm{g} / \mathrm{mL})}\right.\end{array}$ & $\begin{array}{c}\text { ABTS } \\
\left(\mathrm{IC}_{50, \mu \mathrm{g} / \mathrm{mL})}\right.\end{array}$ & $\begin{array}{l}\text { Hydroxyl radical } \\
\text { (IC } 50, \mu \mathrm{g} / \mathrm{mL})\end{array}$ & $\begin{array}{l}\text { Anion superoxide } \\
\left.\text { (IC }{ }_{50}, \mu \mathrm{g} / \mathrm{mL}\right)\end{array}$ & $\begin{array}{l}\text { Reducing power } \\
\left(\mathrm{EC}_{50, \mu \mathrm{g} / \mathrm{mL})}\right.\end{array}$ \\
\hline CRE & $94.66 \pm 1.75^{* * *}$ & $25.77 \pm 0.69^{* * *}$ & $406.67 \pm 1.4^{* * *}$ & $445.77 \pm 30.23^{* * *}$ & $53.12 \pm 0.017^{* * *}$ \\
\hline $\mathrm{AQE}$ & $40.88 \pm 4.03 \mathrm{~ns}$ & $26.33 \pm 0.52^{* * *}$ & $189.17 \pm 0.68^{* * *}$ & $147.78 \pm 1.72^{* * *}$ & $50.56 \pm 0.011^{* * *}$ \\
\hline EAE & $34.22 \pm 1.86^{\mathrm{ns}}$ & $4.99 \pm 0.55^{* *}$ & $239.17 \pm 1.71^{* * *}$ & $202.77 \pm 9.22^{* * *}$ & $17.06 \pm 0.014^{* * *}$ \\
\hline CHE & $54.66 \pm 2.42^{* * *}$ & $7.33 \pm 0.62^{* * *}$ & ND & $562.78 \pm 13.72^{* * *}$ & $24.2 \pm 0.006^{* * *}$ \\
\hline BHT & $33.99 \pm 4.42$ & $1.66 \pm 0.26$ & ------- & ------ & $4.393 \pm 0.014$ \\
\hline Vit C & ------- & ------- & $75 \pm 2.24$ & $7.04 \pm 1.46$ & ------- \\
\hline
\end{tabular}

Values are means of triplicate determinations $(\mathrm{n}=3) \pm \mathrm{SD}$. ND: not determined. ${ }^{* *} \mathrm{P}<0.01$; ${ }^{* * *} \mathrm{P}<0.001$; ns: not significant compared to BHT or Vitamin C.

\section{ABTS radical cation scavenging activity}

As well as DPPH, ABTS scavenging activity of all extracts was concentration-dependent (Figure 2). The IC 50 values of different extracts were ranged from $4.99 \pm 0.55 \mu \mathrm{g} / \mathrm{mL}$ for EAE to $26.33 \pm 0.52 \mu \mathrm{g} / \mathrm{mL}$ for AQE (Table 2). Again, EAE exhibited the highest antioxidant activity compared to other extracts. This activity was similar to that obtained with BHT. The correlation analysis indicated the presence of a good relationship between phenolic compounds and ABTS antioxidant activity of the extracts of D. maritima $(\mathrm{r}=0.779$ for total phenolic, $r=0.808$ for flavonoid and $r=0.847$ for tannin).

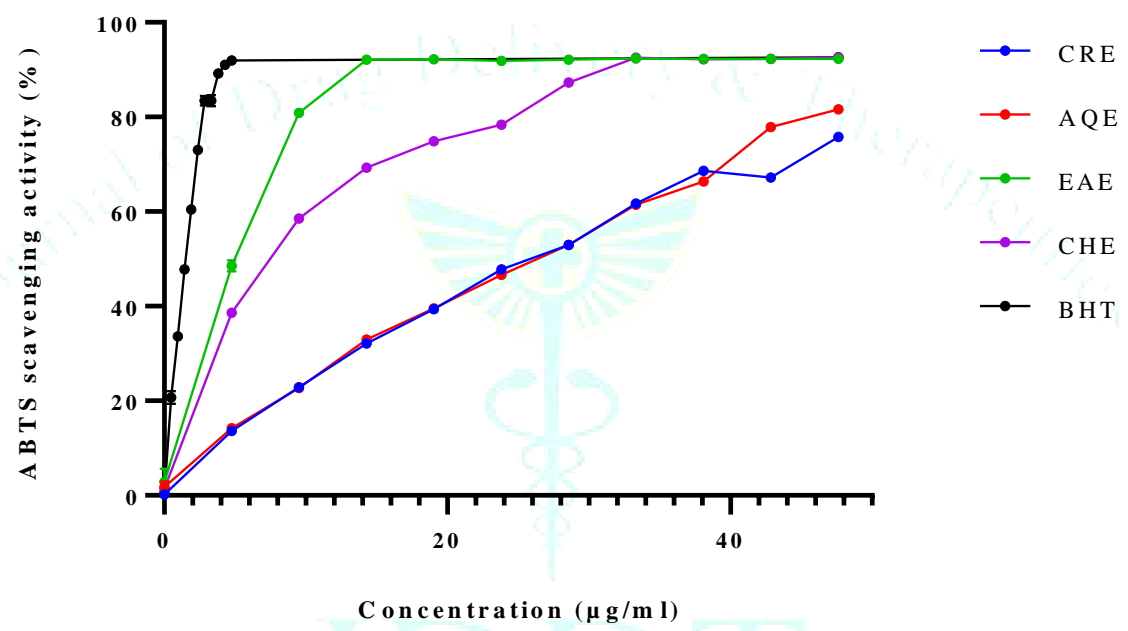

Figure 2: ABTS radical scavenging activity of $D$. maritima extracts and BHT. Values are means of triplicate determinations (n=3) \pm SD.

\section{Superoxide anion scavenging activity}

The studied extracts exerted a superoxide scavenging activity with a concentration-dependent manner (Figure 3).
Table 2 showed that AQE was the most effective extract with the lowest $\mathrm{IC}_{50}$, but this value was significantly $(\mathrm{P}<0.001)$ higher than that of vitamin $\mathrm{C}$.

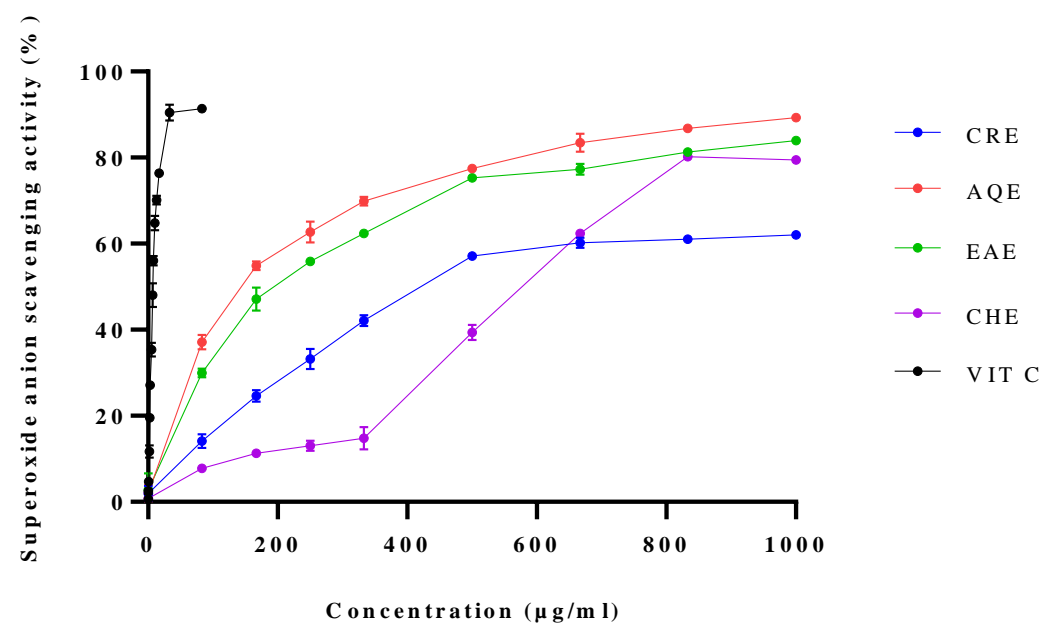

Figure 3: Superoxide anion scavenging activity of D. maritima extracts and vitamin C. Values are means of triplicate determinations $(n=3) \pm S D$. 


\section{Hydroxyl radical scavenging activity}

Figure 4 showed that all extracts and vitamin $C$ can scavenge hydroxyl radicals. Among D. maritima extracts, AQE was the strongest radical scavenger followed by EAE (Table 2). The hydroxyl radical scavenging ability was in descending order (Vitamin $\mathrm{C}>\mathrm{AQE}>\mathrm{EAE}>\mathrm{CRE}>\mathrm{CHE}$ ).

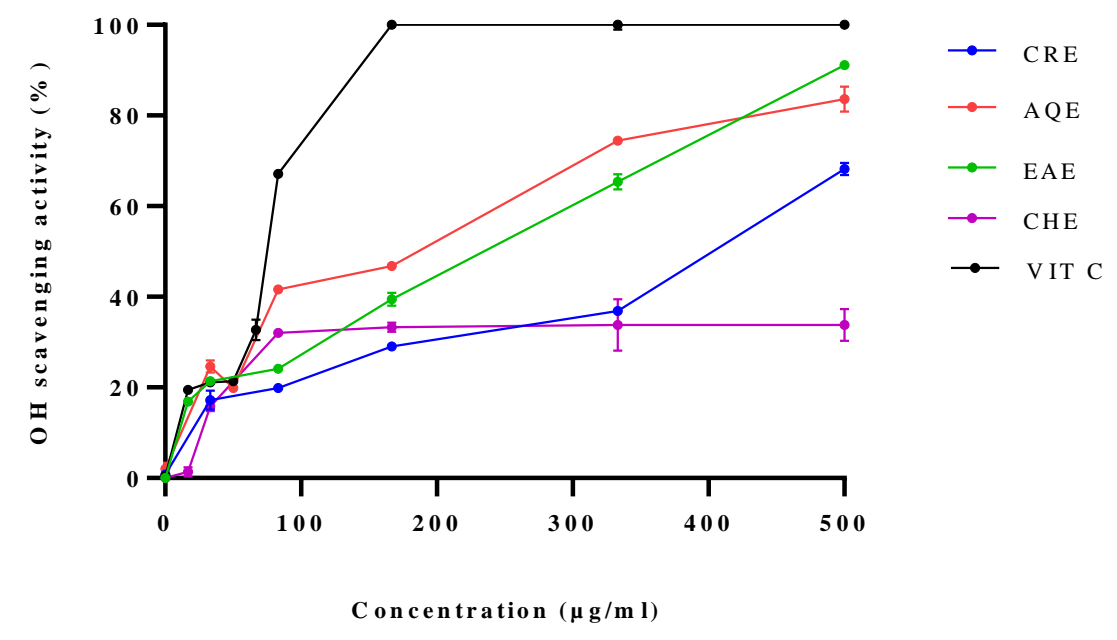

Figure 4: Hydroxyl radical scavenging activity of $D$. maritima extracts and Vitamin C. Values are means of triplicate determinations $(n=3) \pm S D$.

\section{Reducing power}

All the extracts exhibited a ferric reducing capacity in a concentration-dependent manner (Figure 5). A strong activity was exerted by EAE (Table 2), but this activity was lower than that of BHT. The reducing power of samples was in the following order: $\mathrm{BHT}>\mathrm{EAE}>\mathrm{CHE}>\mathrm{AQE}>\mathrm{CRE}$. As well as ABTS, the results showed a significant correlation between phenolic compounds in D. maritima extracts and their reducing power $(\mathrm{r}=0.787$ for total phenolic, $\mathrm{r}=0.804$ for total flavonoid and $r=0.811$ for total tannin).

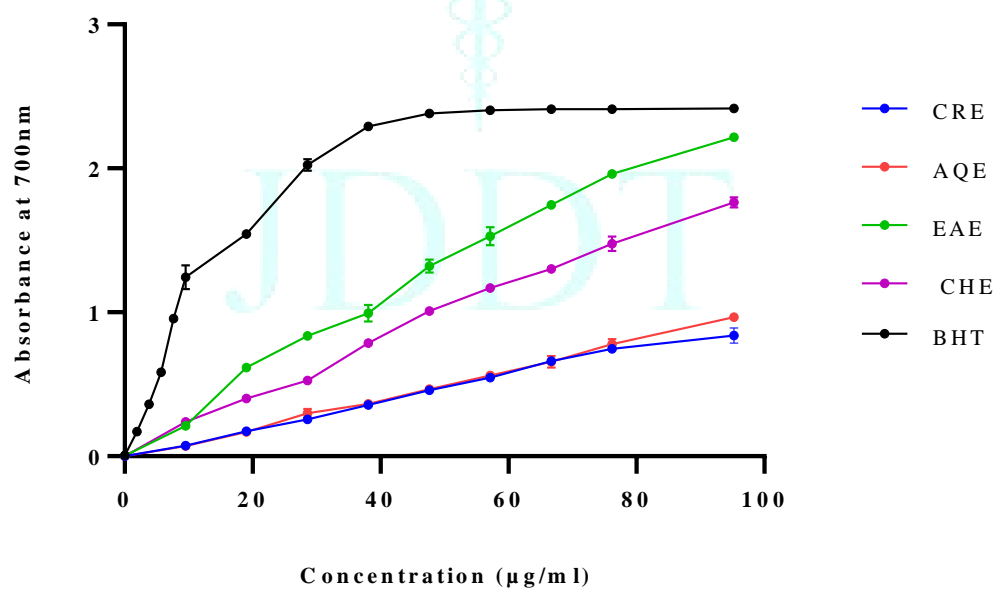

Figure 5: Reducing power of $D$. maritima extracts and BHT. Values are means of triplicate determinations $(\mathrm{n}=3) \pm \mathrm{SD}$. 


\section{Inhibition of $\beta$-carotene bleaching}

Figure 6 showed that all extracts inhibit $\beta$-carotene oxidation and bleaching for 48hours. AQE exerted the strongest inhibition on $\beta$-carotene oxidation (71\%) followed by $\mathrm{CHE}$ (56\%), EAE (30\%), and CRE (20\%).

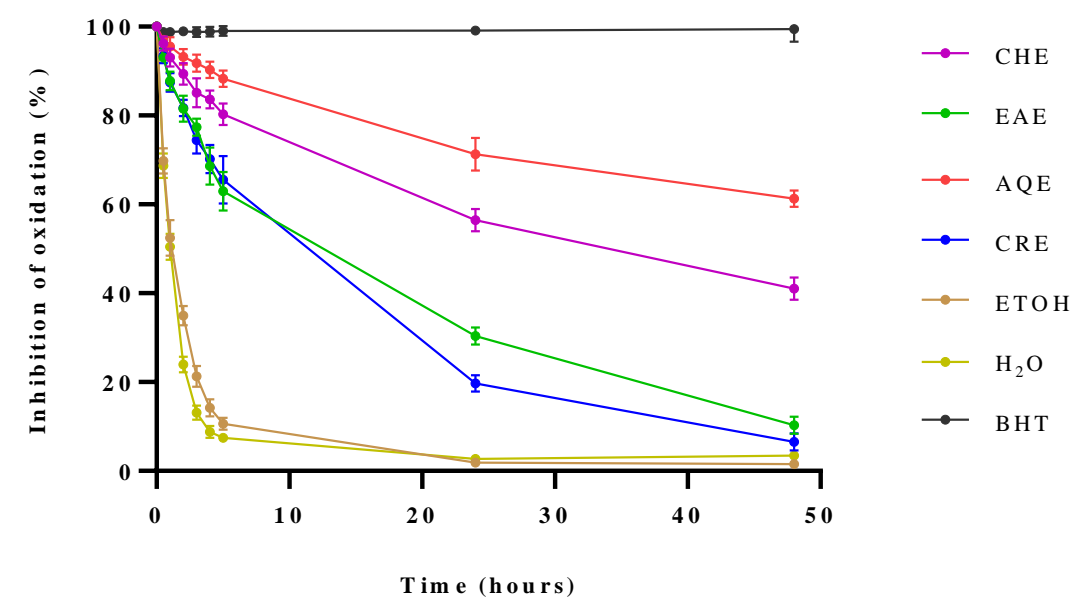

Figure 6: Kinetic of the inhibition of linoleic acid/ $\beta$-carotene oxidation by $D$. maritima extracts and BHT. Values are means of triplicate determinations $(\mathrm{n}=3) \pm \mathrm{SD}$.

\section{Anti-hemolytic activity}

The addition of AAPH to the blood solution induced erythrocytes hemolysis after $125 \mathrm{~min}$ of incubation, leading to a maximum hemolysis at $220 \mathrm{~min}$ (Figure 7 ). However, the pre-incubation of erythrocytes with different concentrations of extracts or Trolox attenuated significantly AAPH-induced erythrocyte hemolysis in a concentration- and timedependent manner.

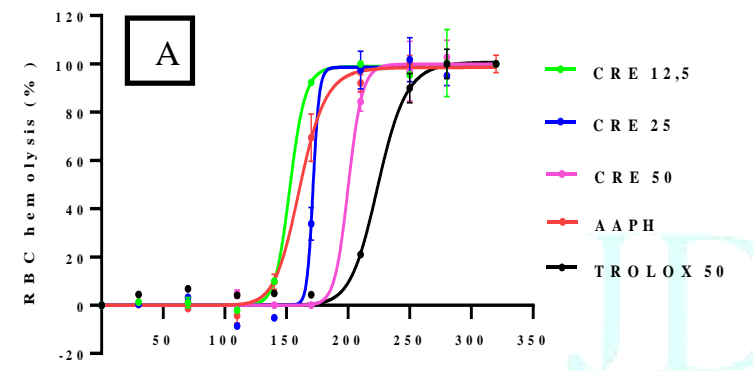

T im e (m in)

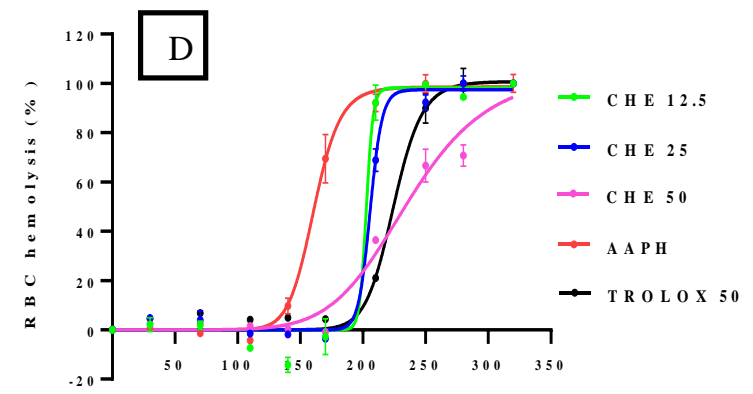

T im e ( $m$ in $)$
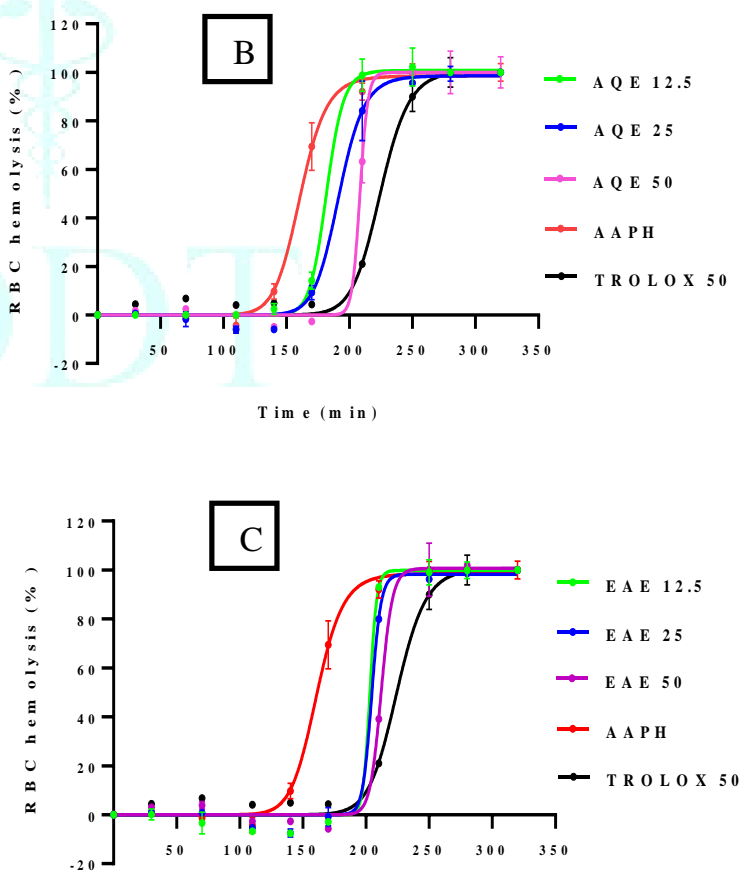

T im e ( $m$ in )

Figure 7: Inhibition of red blood cells hemolysis by D. maritima extracts and Trolox. Values are means of triplicate determinations $(n=3) \pm S D$. 
Figure 8 indicated that all extracts exhibited a high protective effect against RBC hemolysis and increased significantly the half time hemolysis compared to AAPH alone. Among the extracts, CHE was the most effective (half time of hemolysis $=223.4 \mathrm{~min})$.

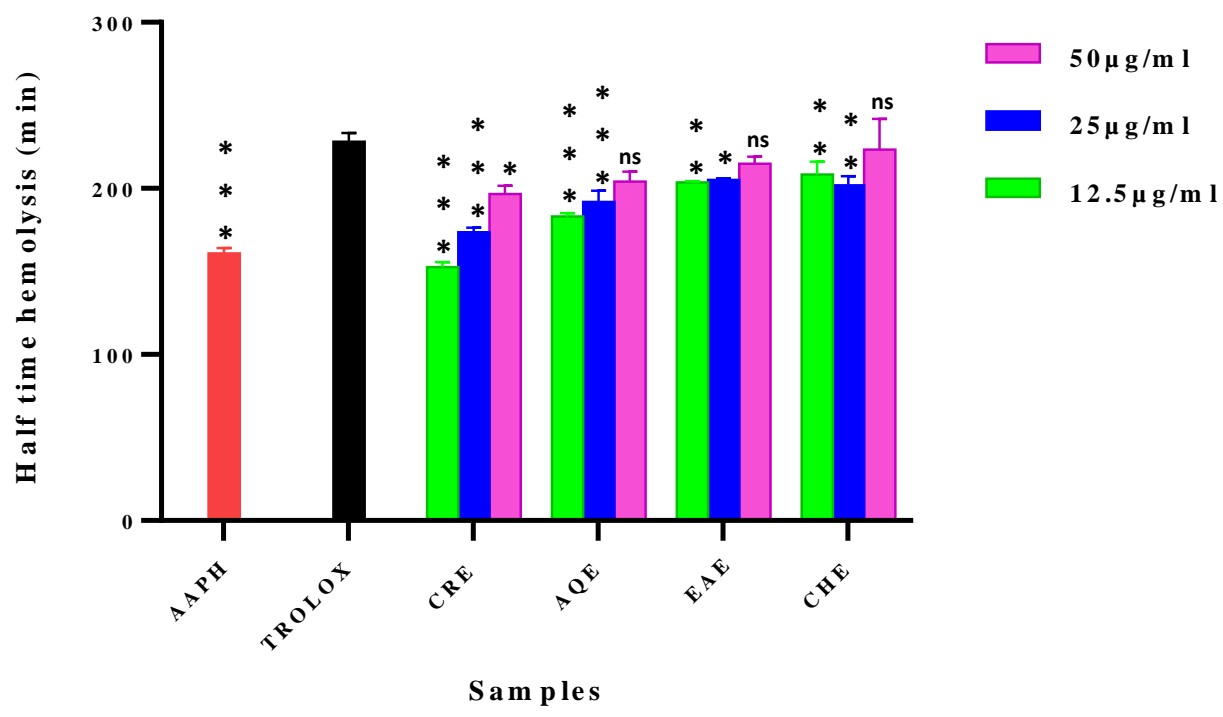

Figure 8: Half-time hemolysis of RBC by $D$. maritima extracts $(12.5,25,50 \mu \mathrm{g} / \mathrm{ml})$. Values are means of triplicate $(\mathrm{n}=3) \pm \mathrm{SD}$. ${ }^{*} \mathrm{P}<0.05$; ${ }^{* *} \mathrm{P}<0.01 ;{ }^{* * *}<0.001$; ns: not significant compared to Trolox $(50 \mu \mathrm{g} / \mathrm{ml})$.

\section{DISCUSSION}

The present study revealed that extracts of $D$. maritima flowers are relatively rich in phenolic compounds, especially tannins. Similar studies have indicated that tubers and leaves of D. maritima are rich in phenolic compounds 22,23 .

Radical scavenging and antioxidant properties of plant extracts are associated with their phytochemical content 24 . However, using a single assay to estimate the antioxidant properties may be insufficient, because it could be influenced by many factors. For this reason, it is very important to carry out more than one type of antioxidant assay to cover the different mechanisms of the antioxidant activity25. In this study, DPPH, ABTS, hydroxyl radical and superoxide anion assays were used to estimate the radical scavenging properties of D. maritima.

DPPH radical scavenging activity is an easy, rapid, and sensitive way to study the antioxidant activity ${ }^{26}$. DPPH• is a stable free radical, whose color changes from violet to yellow after reduction by hydrogen donating antioxidants of plant extracts $^{27}$. Otherwise, ABTS $\bullet+$ is relatively stable but readily reduced by antioxidants leading to its decolorization. This assay is an excellent tool to determine the antioxidant activity of hydrogen-donating antioxidants and chainbreaking antioxidants ${ }^{16}$. D. maritima exhibits a scavenging activity against both DPPH and ABTS radicals. This ability may be due to the presence of phenolic compounds especially tannins. Hagerman et al. ${ }^{28}$ have reported that the high molecular weight phenolic compounds such as tannins have more ability to quench free radicals (ABTS•+). This effectiveness depends on the molecular weight, the number of aromatic rings, and the nature of hydroxyl group substitution. These facts could explain the presence of a high correlation between ABTS•+ radical scavenging and tannins content in D. maritima extracts. The results of this study are following other studies that indicated that extracts of $D$. maritima bulbs and leaves or $D$. indica bulbs are good radical scavengers $^{22,29}$.
Hydroxyl radical is the most reactive free radical formed in biological systems and it can damage almost every molecule in living cells, such as fatty acids, proteins, and DNA inducing severe cellular damages ${ }^{30}$. Therefore, the removal of hydroxyl radicals can protect humans against several diseases $^{31}$. Although superoxide anion is a weak oxidant, it ultimately produces powerful and dangerous hydroxyl radicals, which contributes to oxidative stress ${ }^{32}$. Results revealed that ethyl acetate extract and chloroform extract of D. maritima displayed different potential in scavenging hydroxyl radical and superoxide anions. This potential is positively associated with the amount of total phenolic compounds in the extracts, which have active hydrogen donor ability of hydroxyl substitution 33 .

Reducing power is used as a significant reflection of the antioxidant activity. The reducing property is generally attributed to the presence of reductants. The antioxidant action of reductants is based on the breaking of the free radical chain by electron donation. Moreover, reductants react with the precursors of peroxide, thus preventing peroxide formation ${ }^{34}$. The results presented in this study indicated the presence of a very good correlation between tannin contents and the reducing power of D. maritima extracts. According to this finding, it seems that reducing the activity of D. maritima extracts is due to the presence of phenolics such as tannins. Indeed, these compounds may act as reductants by donating the electrons and reacting with free radicals to convert them to more stable products and terminate radical chain reaction ${ }^{27}$. A relationship between the phenolic constituents and reducing power activity has been reported for several plant extracts ${ }^{27,35}$.

In the $\beta$-carotene/linoleic acid system, the oxidation of linoleic acid generates peroxyl free radicals due to the abstraction of a hydrogen atom from diallylic methylene groups of linoleic acid 36 . The generated peroxyl radicals will oxidize the highly unsaturated molecule of $\beta$-carotene. However, the presence of antioxidants in the extract could minimize the $\beta$-carotene oxidation ${ }^{13}$. This inhibition may be 
due to the hydrogen donating capacity of phenolic compounds. Indeed, several studies that focused on medicinal plants, fruits, or vegetables found a high correlation between phenolic content of extracts and antioxidant activity in the $\beta$-carotene/linoleic acid system $^{27,37}$.

The decomposition of the water-soluble AAPH at physiological temperature generates in vitro free radicals that attack erythrocytes membranes and induce lipid peroxidation, leading to hemolysis. This method is very useful for screening activities of various molecules, especially those having an oxidant or antioxidant activity with a long-term action ${ }^{27}$. Natural antioxidants like phenolic compounds can scavenge and react with free radicals and then terminate the free radical reaction chain. Hence, the suppression of the oxidative modification of erythrocyte lipids by antioxidants constitutes the preferable strategy to prevent hemolysis and cardiovascular diseases ${ }^{38}$.

The pretreatment by $D$. maritima extracts increased significantly the resistance of erythrocytes against hemolysis. It has been reported that the pretreatment with an antioxidant increases the half-time of hemolysis, which links to a good resistance of erythrocytes ${ }^{27}$. This antihemolytic activity could be explained by the inhibition and neutralization of free radicals liberated by AAPH decomposition. Such hypothesis could be supported by the presence of a good relationship between the percentage of hemolysis and reducing power $(r=0.663)$, ABTS $\cdot+(r=$ $0.808)$ and tannins $(r=0.838)$, suggesting that the mechanism of action of the extracts of D. maritima flowers against hemolysis may be related to their content in tannins, reducing power and radical scavenging ability. Several investigators have established the presence of a correlation between phenolic compounds and anti-hemolytic activity in plant extracts 27,39 .

\section{CONCLUSION}

Our finding increases the interest in the use of D. maritima flowers as a source of pharmacological agents. Extracts of $D$. maritima flowers contain high levels of total phenolic compounds, especially tannins and they were able to scavenge free radicals and thereby terminate the radical chain reactions. Further determination of compounds from this plant and the study of other biological effects may provide more information on their medicinal value.

\section{CONFLICT OF INTEREST}

The authors declare that they have no conflicts of interest.

\section{FUNDING}

This work was supported by the Algerian Ministry of Higher Education and Scientific Research (MESRS) [Project number CNEPRU/D01N01UN190120190004].

\section{REFERENCES}

1. Bellakhdar J, La pharmacopée marocaine traditionnelle : Médecine arabe ancienne et savoirs populaires (Ed Le Fennec, Casablanca) 1997. P. 764.

2. Sharaf AT, Sawidis T, Diannelidis BE, Delivopoulos S, Anatomical studies on the adventitious roots of the geophyte Urginea maritima (L.) Baker. J Biol Res, 2006; 5:61-70.

3. Adams M, Bersat C, Kessler M, Hamburger M, Medicinal herbs for the treatment of rheumatic disorders - A survey of European herbals from the $16^{\text {th }}$ and $17^{\text {th }}$ century. J Ethnopharmacol, 2009; 121:343-359.

4. Mehdioui R, Kahouadji A, Etude ethnobotanique auprès de la population riveraine de la forêt d'Amsittène: cas de la
Commune d'Imi n'Tlit (Province d'Essaouira). Bulletin de l'Institut scientifique (Rabat), Sciences de la vie, 2007; 29:11-20.

5. El Hafian M, Benlandini N, Elyacoubi H, Zidane L, Rochdi A Étude floristique et ethnobotanique des plantes médicinales utilisées au niveau de la préfecture d'Agadir-Ida-Outanane (Maroc). J App Biosci, 2014 ; 81:7198-7213.

6. Hmamouchi $\mathrm{M}$, Les plantes médicinales et aromatiques marocaines (Ed Fedala, Rabat) 1999. P. 389.

7. Benkhnigue O, Zidane L, Fadli M, Elyacoubi H, Rochdi A, Douira A, Etude ethnobotanique des plantes médicinales dans la région de Mechraâ Bel Ksiri (Région du Gharb du Maroc). Acta Bot Barcinon, 2010; 53:191-216.

8. Fernandez M, Vega FA, Arrupe T, Renedo J, Flavonoids of squill, Urginea maritima. Phytochemistry, 1972; 11:1534.

9. Spies T, Praznik W, Hofinger A, Altmann F, Nitsch E, Wutka R, The structure of the fructantsinistrin from Urginea maritima. Carbohydr Res, 1992; 235:221-230.

10. Belhaddad OE, Charef N, Ammamra S, Zerargui F, Baghiani A Khennouf S, Arrar L, Chromatographic fractionation, antioxidant and antibacterial activities of Urginea maritima methanolic extract. Pak J Pharm Sci, 2017; 30:127-134.

11. Kopp B, Krenn L, Draxler M, Hoyer A, Terkola R, Vallaster P, Robien W, Bufadienolides from Urginea maritima from Egypt. Phytochemistry, 1996; 42: 513-522.

12. Li HB, Cheng KW, Wong CC, Fan KW, Chen F, Jiang Y, Evaluation of antioxidant capacity and total phenolic content of different fractions of selected microalgae. Food Chem, 2007; 102:771776.

13. Bahorun T, Gressier B, Trotin F, Brunete C, Dine T, Vasseur J, Gazin JC, Pinkas M, Luycky M, Gazin M, Oxygen species scavenging activity of phenolic extract from hawthorn fresh plant organs and pharmaceutical preparation. Arzneimittel Forschung, 1996; 46 (11):1086-1089.

14. Batesmith EC, Haemanalysis of tannins: The concept of relative astringency Phytochemistry, 1973; 12 (4):907-912.

15. Burits M, Bucar F, Antioxidant activity of Nigella sativa essential oil. Phytother Res, 2000; 14:323-328.

16. Re R, Antioxidant activity applying an improved ABTS radical cation decolorization assay. Free Radical Bio Med, 1999; 26:1231-1237.

17. Robak J, Gryglewski RJ, Flavonoids are scavengers of superoxide anions. Biochem Pharmacol, 1988; 37:837-841.

18. Smirnoff N \& Cumbes QJ, Hydroxyl radical scavenging activity of compatible solutes. Phytochemistry, 1989; 28:1057-1060.

19. Prasad KN, Yang B, Dong X, Jiang G, Zhang H, Xie H, Jiang Y, Flavonoid contents and antioxidant activities from Cinnamomum species. Innov Food Sci Emerg Technol, 2009; 10:627-632

20. Kartal N, Sokmen M, Tepe B, Daferera D, Polissiou M \& Sokmen A, Investigation of the antioxidant properties of Ferula orientalis L. using a suitable extraction procedure. Food Chem, 2007; 100:584-589.

21. Takebayashi J, Chen J, Tai A, A method for evaluation of antioxidant activity based on inhibition of free radical-induced erythrocyte hemolysis, In Advanced protocols in oxidative stress II. Methods in molecular biology (Ed Armstrong D, Humana Press, Heidelberg, Germany) 2010. P. 287.

22. Mammadov R, Makasçı-Afacan A, Uysal-Demir D, Görk Ç, Determination of antioxidant activities of different Urginea maritima (L.) Baker plant extracts. Iran J Chem Chem Eng, 2010; 29:47-53.

23. Daoudi A, Bammou M, Haloui Z, Ibijbijen J, Nassiri L, Activité antifongique des extraits aqueux de Calendula officinalis $\mathrm{L}$, Urginea maritima (L.) Baker et Chenopodium ambrosioides L. Eur Sci J, 2017; 13 :1857-7881. 
24. Alabri TH, Al Musalami AH, Hossain MA, Weli AM, Al- Riyami Q, Comparative study of phytochemical screening, antioxidant and antimicrobial capacities of fresh and dry leaves crude plant extracts of Datura metel L. J King Saud Univ Sci, 2014; 26 (3):237-243.

25. Iqbal E, Salim KA, Lim LB, Phytochemical screening, total phenolics, and antioxidant activities of bark and leaf extracts of Goniothalamus velutinus (Airy Shaw) from Brunei Darussalam. J King Saud Univ Sci, 2015; 27 (3):224-32.

26. Koleva II, Van Beek TA, Linssen JPH, de Groot A, Evstatieva LN, Screening of plant extracts for antioxidant activity: a comparative study on three testing methods. Phytochem Analysis, 2002; 13:8-17.

27. Loganayaki N, Siddhuraju P, Manian S, Antioxidant activity and free radical scavenging capacity of phenolic extracts from Helicteres isora L. and Ceiba pentandra L. J Food Sci Technol, 2013; 50 (4):687- 695.

28. Hagerman AE, Riedl KM, Jones GA, Sovik KN, Ritchard NT, Hartzfeld PW, Riechel TL, High molecular weight plant polyphenolics (tannins) as biological antioxidants. J Agr Food Chem, 1998; 46: 1887-1892.

29. Banani M, Shivakameshwari MN, Shubarani R, Antioxidant activity in two species of Urginea steinhill, Hyacinthaceae. Int J Recent Sci Res, 2015: 6 (5): 3807-3811.

30. Sakanaka S, Tachibana Y, Okada Y, Preparation and antioxidant properties of extracts of Japanese persimmon of Leaf tea (kakinohacha). Food Chem, 2005; 89: 569-575.

31. You L, Zhao M, Cui C, Zhao H, Yang B, Effect of degree of hydrolysis on the antioxidant activity of loach (Misgurnus anguillicaudatus) protein hydrolysates. Innov Food Sci Emerg Technol, 2009; 10:235-240.

32. Nur Alam M, Bristi NJ, Rafiquzzaman M, Review on in vivo and in vitro methods evaluation of antioxidant activity. Saudi Pharm J, 2013; 21: 143-152.

33. Kumar S, Pandey AK, Chemistry and biological activities of flavonoids: an overview. Sci World J, 2013; 1-16.

34. Wong DZ, Kadir HA, Ling SK, Bioassay-guided isolation of neuroprotective compounds from Loranthus parasiticus against $\mathrm{H}_{2} \mathrm{O}_{2}$-induced oxidative damage in NG108-15 cells. J Ethnopharmacol, 2012; 139:256- 264.

35. Felipe González A, Hernández Balmaseda I, Gaitén YIG, Lizama RS, García LMC, Pieters L, Guerra IR, Hernández RD, Phytochemical study and antioxidant capacity of three fractions from the stem of Caesalpinia bahamensis Lam. J Pharm Pharmacogn Res, 2018; 7:12.

36. Lee S, Shin DS, Oh KB, Shin $\mathrm{KH}$, In vivo anti-oxidant activities of tectochrysin. Arch Pharm Res, 2003; 26 (1):43-46.

37. Maisarah AM, Nurul Amira B, Asmah R, Fauziah O, Antioxidant analysis of different parts of Carica papaya. Int Food Res J, 2013; 20 (3):1043-1048.

38. Sesso HD, Gaziano JM, Liu S, Buring JE, Flavonoid intake and the risk of cardiovascular disease in women. Am J Clin Nutr, 2003; 77:1400-1408.

39. Ramchoun M, Sellam K, Harnafi H, Alem C, Benlyas M, Khallouki F, Amrani S, Investigation of antioxidant and anti-hemolytic properties of Thymus satureioides collected from Tafilalet Region, southeast of Morocco. Asian Pac J Trop Biomed, 2015; 5 (2):93-100. 